\title{
SNAP MOR \\ (TRADISI PENANGKAPAN IKAN MASYARAKAT BIAK)
}

\author{
Alfasis Romarak Ap \\ Fakultas Keguruan dan Ilmu Pendidikan \\ Universitas Cenderawasih-Jayapura \\ noackmandowen_nocky@yahoo.com
}

\begin{abstract}
The purpose of this research is to find out the tradition of looking for fish for breeders by taking a mor snap. This research was carried out in Biak Island and was used to use purposive sampling technique, to obtain samples which are communities from urban coastal areas and rural coasts in Biak Island who know about the tradition of snap mor. This study concludes that the tradition of snap mor conducted by the Biak community has ways and techniques of fishing through the snap mor tradition that is adjusted based on the local wisdom of each region that has been studied from generation to generation.
\end{abstract}

Keywords: Snap Mor, Tradition, Fishing

\section{A. PENDAHULUAN}

Wilayah Negara Kesatuan Republik Indonesia sebagian besar wilayanya adalah laut dan sebagian lainnya wilayah pesisir .Wilayah Laut Indonesia adalah yang terpanjang ke dua di dunia.Hal ini menyebabkan masyarakat nelayan di pesisir mempunyai mata pencaharian utama bergantung pada sumberdaya laut. masyarakat nelayan sering kali tergantung pada perubahan musim. Pengelolaan sumberdaya alam di sekitar laut harus disesuaikan dengan kondis geografis dan kearifan lokal pada setiap daerah karena memiliki karakteristik yang berbeda-beda. Pada suatu komunitas tertentu dapat ditemukan keraifan lokal yang terkait dengan pengelolaan sumberdaya alam sebagai tata pengaturan lokal yang telah ada sejak masa lalu. tidak hanya berfungsi sebagai ciri khas suatu komunitas saja, tetapi juga berfungsi sebagai upaya untuk pelestarian lingkungan ekologis suatu komunitas masyarakat.

Pengelolaan sumber daya laut yang lestari dan berkelanjutan sudah diterapkan sejak abad ke-16 oleh masyarakat adat yang tersebar di wilayah pesisir dan pulau-pulau kecil di Indonesia. Dalam masyarakat mereka mengenal yang namannya tradisi, kebiasaan, dan budaya yang biasa kita sebut kearifan lokal. Tradisi (Bahasa Latin: traditio, "diteruskan") atau kebiasaan, dalam pengertian yang paling sederhana adalah sesuatu yang telah dilakukan sejak lama dan menjadi bagian dari kehidupan suatu kelompok masyarakat, biasanya dari suatu negara, kebudayaan, waktu, atau agama yang sama. Kebiasaan merupakan norma yang keberadaannya dalam masyarakat diterima sebagai aturan yang mengikat walaupun tidak ditetapkan oleh pemerintah. Budaya adalah suatu cara hidup yang berkembang dan dimiliki bersama oleh sebuah kelompok orang dan diwariskan dari generasi ke generasi. Budaya terbentuk dari banyak unsur yang rumit, termasuk sistem agama dan politik, adat istiadat, bahasa, perkakas, pakaian, bangunan, dan karya seni. .

Kearifan lokal adalah semua bentuk pengetahuan, keyakinan, pemahaman, atau wawasan serta adat kebiasaan atau etika yang menuntun perilaku manusia dalam kehidupan didalam komunitas ekologi. Semua kearifan lokal ini dihayati, dipraktekkan, diajarkan, dan diwariskan 
dari geerasi kegenerasi, sekaligus membentuk pola perilaku manusia terhadap sesama manusia, alam maupun gaib. (Keraf, 2002).

Kearifan tradisional yang tercermin dalam sistem pengetahuan dan teknologi lokal di berbagai daerah secara dominan masih mewarnai nilai-nilai adat sebagaimana tampak dari cara-cara mereka melakukan prinsip-prinsip konservasi, managemen dan eksploitasi sumber daya alam, ekonomi, dan sosial (Hapsari dan Dinar, 2015).

Salah satu contoh kearifan lokal yaitu Tradisi masyarakat Biak dalam hal mencari ikan yang disebut "Snap Mor". Kearifan lokal merupakan gagasan konseptual yang hidup dalam masyarakat, tumbuh dan berkembang secara terus-menerus dalam kesadaran masyarakat, yang berfungsi dalam mengatur kehidupan masyarakat dari yang sifatnya berkaitan dengan kehidupan yang sakral sampai yang profan. Kearifan loka/tradisional merupakan bagian dari etika dan moralitas yang membantu manusia untuk menjawab pertanyaan moral, apa yang harus bertindak khususnya di bidang pengolaan lingkungan dan sumberdaya alam dan diwariskan dari generasi kegenerasi yang lain.

Tradisi snap mor ini sangat dekat dengan laut dan digelar pada masa air laut pada siklus surut terendah dan pasang tertinggi. Pada siklus surut terendah, kegiatan snap mor ini dilakukan di daerah dangkal dan bebas dari area zona pecah gelombang. Siklus surut terendah dan pasang tertinggi biasanya berlangsung pada bulan Juli dan Agustus. Tradisi Snap mor yang tetap terjaga sebenarnya menunjukkan kemampuan masyarakat asli Biak yang secara turun-temurun mengenali siklus pasang surut. Mereka mampu membaca kondisi laut dan tanda-tanda alam lain untuk menentukan kapan dan di mana ikanikan dapat diperoleh.

Tradisi snap mor adalah merupakan salah satu bentuk ucapan syukur atas berkat yang dirayakan bersama kerabat dan seluruh komunitas masyarakat di Biak, biasanya mereka yang sudah lanjut usia tidak turut aktif dalam menangkap ikan, Dahulu para pemudalah yang menyisihkan tangkapan untuk dibagi-bagikan kepada mereka yang sudah di usia tua. Hal itu merupakan sebuah ekspresi budaya lokal, yang di dalamnya mengungkap nilai-nilai kebersamaan menjadi satu unsur penting dalam kehidupan mereka.

\section{B. RUMUSAN MASALAH}

Berdasarkan penjelasan pada latar belakang di atas maka permasalahan yang dapat dirumuskan adalah (1) apa itu Snap Mor dalam budaya orang Biak ? (2) Bagaimana proses pelaksanaanSnap Mor ? (3) Apa makna dan fungsi Snap Mor dalam budaya orang Biak ? (4) Bagaimana upaya pelestarian tradisi Snap Mor oleh masyarakat Biak dan Pemerintah.

\section{LANDASAN TEORITIK}

\subsection{Beberapa Unsur Budaya Orang} Biak

Bagian ini memberi informasi tentang kebudayaan orang Orang yang mendiami pulau Biak, Supiori, Numfor, kepulauan Padaido dan kepulauan Waigeo / Raja Ampat. Untuk memahami kebudayaan orang Biak penjelasannya dimulai dari nama dan latar belakang sejarah orang orang Biak kemudian dilanjutkan dengan beberapa unsur budayanya, yaitu antara lain : unsur sistem mata pencaharian, sistem kekerabatan dan perkawinan, sistem kepemimpinan, religi dan kesenian.

\section{Sejarah Asal Usul Orang Biak dan Nama Biak}

Sampai saat ini belum terdapat sumber-sumber ilmiah yang dapat memberikan keterangan mengenai asalusul orang Biak, sehinga salah satu sumber tentang sejarah asal-usul orang Biak masih diperoleh dari keterangan ceritra rakyat yang bersifat mite. Menurut mite, nenek moyang orang Biak berasal dari satu daerah yang terletak disebelah timur, tempat 
Matahari terbit. Moyang pertama datang kedaerah kepulauan ini dengan menggunakan perahu. Ada beberapa versi cerita kedatangan moyang pertama itu,. Salah satu versi menceritakan bahwa moyang pertama dari orang Biak terdiri dari sepasang suami istri yang dihanyutkan oleh air bah diatas sebuah perahu dan ketika air surut kembali terdampar diatas satu bukit yang kemudian diberi nama Sarwambo oleh suami istri tersebut. Bukit ini terdapat dibagian Timur Laut (disebelah selatan kampung Korem sekarang). Dari bukit Sarwambo, moyang pertama bersama anakanaknya berpindah ke tepi sungai Korem, dan kemudian berkembang dan menyebar keseluruh Biak-Numfor.

Sejarah mengenai kontak orang Biak dengan dunia luar, telah dilakukan jauh sebelum kedatangan bangsa eropa ke Papua. Menurut sumber lisan, kontak yang dilakukan orang Biak dengan dunia luar diketahui melalui tokoh-tokoh legendaris seperti Fakok dan Pasref, dan beberapa informasi dari Kesultanan Ternate dan Tidore (Kamma 1953:151). Hubungan tersebut terjadi dengan penduduk didaerah pesisir Utara Kepala Burung, Kepulauan Raja Ampat dan dengan penduduk Kepulauan Maluku. Kontak orang Biak dengan dunia luar terjadi terutama melalui hubungan perdagangan dan ekspedisiekspedisi perang dan pengayauan.

Pada masa pemerintahan Kolonial Belanda hingga decade 1960-an di Papua, nama yang digunakan untuk menamakan Kepulauan Biak-Numfor adalah Schouten Eilanden, yang disesuaikan dengan nama orang Eropa pertama berkebangsaan Belanda yang mengunjungi daerah ini pada awal abad ke-17. Nama-nama lain yang sering dijumpai dalam laporan-laporan tua untuk penduduk dan daerah kepulauan ini adalah Numfor atau Wiak. Fonem $w$ pada kata wiak sebenarnya berasal dari fonem $v$ yang kemudian berubah menjadi $b$ sehingga muncullah kata Biak seperti yang digunakan sekarang. Dua nama terakhir itulah yang kemudian digabungkan menjadi satu nama yaitu Biak-Numfor, dengan tanda garis mendatar diantara dua kata itu sebagai tanda penghubung anatara dua kata tersebut, yang dipakai secara resmi untuk menamakan daerah dan penduduk yang mendiami pulau-pulau yang terletak disebelah Utara Teluk Cenderawasih. Ada beberapa versi pendapat tentang asal-usul kedua nama tersebut di atas.

Pertama ialah bahwa nama Biak yang berasal dari kata v'iak itu pada mulanya merupakan 'satu kata yang dipakai untuk menamakan penduduk yang bertempat tinggal di daerah pedalaman pulau-pulau tersebut. Kata tersebut mengandung pengertian orang-orang yang tinggal didalam hutan, orang-orang yang tidak pandai kelautan, seperti misalnya tidak cakap menangkap ikan dilaut, tidak pandai berlayar dilaut dan menyeberangi lautan yang luas dan lain sebagainya. Nama ini diberikan oleh penduduk pesisir pulaupualau ini yang memiliki kemampuan kemaritiman yang baik. Walaupun nama tersebut pada awalnya dimaksudkan untuk menghina kelompok penduduk tertentu, nama ini kemudian mulai diterima dan digunakan sebagai nama resmi untuk penduduk didaerah ini.

Pendapat lain berasal dari keterangan ceritra lisan rakyat berupa mite, yang menceritakan bahwa nama itu berasal dari warga klen Burdam yang meninggalkan Pulau Biak akibat pertengkaran mereka dengan warga klen Mandowen. Menurut mite itu, warga klen Burdam memutuskan untuk berangkat meninggalkan Pulau Warmambo (nama asli Pulau Biak) untuk menetap disuatu tempat yang letaknya jauh, sehingga pulau Warmambo hilang dari pandangan mata. Demikianlah mereka berangkat, tetapi setiap kali mereka menoleh kebelakang, mereka melihat Pulau Warmambo nampak di atas permukaan laut. Keadaan ini menyebabkan mereka berkata v'iak wer, atau v'iak, yang berarti ia muncul lagi.

Kata inilah yang kemudian dipakai oleh mereka yang pergi untuk menamakan 
Pulau Warmambo, dan hingga sekarang nama itulah yang tetap dipakai. (Kamma 1978:29-33). Kata Biak secara resmi dipakai sebagai nama untuk menyebut daerah dan penduduknya yaitu pada saat terbentuknya lembaga Kankain Karkara Biak pada tahun 1947 (De Bruijn 1965:87). Lembaga tersebut merupakan pengembangan dari lembaga adat Kankain Karkara Mnu yaitu satu Lembaga Adat yang mempunyai fungsi mengatur kehidupan bersama dalam suatu komunitas yang disebut Mnu atau Kampung.

Sedangkan nama Numfor berasal dari nama Pulau dan Golongan penduduk asli Pulau Numfor. Penggabungan nama Biak dan Numfor menjadi satu nama dan pemakaiannya secara resmi terjadi pada saat terbentuknya Lembaga Dewan Daerah di Kepulauan Schouten yang diberi nama Dewan Daerah Biak-Numfor pada tahun 1959.

\section{Sistem Mata Pencaharian Hidup}

Secara budaya orang Biak mengenal empat mata pencaharian pokok, yaitu menangkap ikan, berburu, meramu dan bercocok tanam, namun setelah terjadi kontak dengan orang luar, orang Biak juga melakukan kegiatan perdagangan. Setiap kampung yang mereka singgahi mereka tidur dan dagang parang sehingga mereka memiliki teman dagang dikampungkampung itu yang mereka sebut dengan istilah Manibob (teman dagang).

Forde dalam Poerwanto (2010), menyatakan bahwa hakikat hubungan antara kegiatan manusia dengan lingkungannya dijembatani oleh pola-pola kebudayaan yang dimiliki oleh makhluk manusia. Melalui kebudayaan yang dimilikinya, manusia mampu mengadaptasi diri dengan lingkungannya, sehingga ia mampu melangsungkan hidupnya.

Berikut ini adalah penjelasan masing-masing sistem mata pencaharian pada orang Biak yaitu antara lain :

a. Menangkap ikan

Menangkap ikan merupakan mata pencaharian yang umumnya dilakukan oleh hampir semua orang Biak, khususnya yang menetap didaerah pesisir gugusan kepulauan Biak-Numfor. Menangkap ikan dapat dikerjakan oleh siapa saja, kapan dan dimana saja, namun ada beberapa jenis ikan yang dalam penangkapannya dibutuhkan keahlian dan tehnik khusus, seperti penangkapan Kasem (Ikan Hiu).

\section{b. Berburu}

Berburu atau kosamsam /ifrardenem merupakan salah satu jenis mata pencaharian orang Biak. Jenis mata pencahrian ini umumnya dilakukan oleh orang Biak yang tinggal di daerah pedalaman Biak. dan juga dilakukan oleh orang Biak yang menetap di daerah pesisir pantai sebagai pekerjaan sambilan. Bagi orang Biak di daerah pesisiran pantai, aktivitas beberuru dilakukan bila mereka sedang bermalam di kebun, atau juga disaat situasi laut sedang dalam keadaan yang tidak memungkinkan untuk melaut, misalnya pada saat musim ombak (Oktober-Februari).

\section{c. Meramu}

Meramu sebagai salah satu bentuk mata pencaharian hidup orang Biak, telah dilakukan sejak dahulu, bahkan merupakan aktivitas yang paling sering dilakukan oleh orang Biak. Meramu dilakukan baik di hutan maupun di rawa-rawa. Aktivitas meramu dilakukan oleh siapa saja, kapan pun dan dimana saja. meramu di hutan menjadi kegiatan sambilan ketika orang pergi ke kebun ataupun berburu. Tumbuhan yang diramu dihutan seperti Jamur dan Genemo. Sedangkan meramu di rawa-rawa umumnya adalah sagu (menokok sagu) dan ulat sagu. Meramu Jamur dan Genemo tidak membutuhkan tehnik dan keahlian khusus, namun 
meramu Sagu membutuhkan tehnik dan keahlian khusus.

\section{d. Bercocok Tanam}

Mata pencaharian bercocok tanam yang disebut Amom dalam bahasa Biak, merupakan aktivitas yang umum dilakukan oleh seluruh orang Biak. Kondisi topografi lingkungan yang tidak memungkinkan untuk tercapainya surplus porduksi, menyebabkan sehingga hasil dari aktivitas bercocok tanam umumnya tidak diperdagangkan, namun hanya untuk dikonsumsi sendiri. Jika terdapat surplus produksi, maka hasilnya akan diperdagangkan ke kota untuk mencari biaya tambahan dalam rangka memenuhi kebutuhan hidup lainnya. Kondisi yang seperti ini telah mendorong orang Biak untuk melakukan aktivitas bercocok tanam sebagai aktivitas rutinnya setiap hari.

\section{e. Sistem Kekerabatan}

Dalam kehidupan masyarakat sederhana masih memiliki sujuta pranata sosial yang mengatur tatacara hidup yang dianggap sebagai adatistiadatnya. Adat istiadat ini sebagian besar berhubungan erat dengan sisten kekerabatan yang dianut oleh suatu kelompok masyarakat. Parsudi Suparlan mengemukakan bahwa dalam sistem kekerabatan terdapat petunjuk-petunjuk yang mencakup apa peran pria dan wanita, persutubuhan dan perkawinan, siapasiapa yang boleh dan tidak boleh dijadikan sebagai pasangan hidup, serta siapa-siapa (pria dan wanita) yang pantas dijadikan pasangan hidup utntuk kebahagiaan secara biologi, sosial dan kebudayaan.

\footnotetext{
${ }^{2}$ satuan social yang amat erat, dan hidup tinggal bersama pada satu rumah tradisional (Aberdado) atau biasanya disebut keluarga luas.
}

1
Selain utu, melalui sisatem kekerabatan ada petunjuk yang m,encakup peran (hak dan kewajiban) orang tua, dan kerabat dari calon pengantung dalam peraturan perawinan dan kehidupan keluarga, baik yang baru membentuk maupun yang sudah mampan (Suparlan,1989:3).

Untuk itu maka prinsip keturunan sangat penting dalam menentukan perang (hak dan kewajiban) seseorang dalam struktru sosial suatu kelompok masyarakat. Yang mana hal ini terjadi pula dalam kehidupan sosial orang Biak yang menganut sistem kekerabatan Patrilineal.

\section{Kelompok-kelompok} kekerabatan.

Kelompok-kelompok

kekerabatan sangat penting dalam kehidupan manusia sebagai mahluk sosial yang mempunyai kebudayaan.

Karena kelompok-kelompok dalam suatu sistem kekerabatan merupakan sarana pengikat sosial yang amat penting walaupun pada setiap suku berbeda satu sama lainnya sesuai dengan prinsip keturunan yang dianutnya.

Telah dikemukakan bahwa orang Biak menganut sistem patrilineal, sehingga dalam hubungan garis keturunan dihitung melalui ayah. Dan pada dasarnya orang Biak mengenal 3 (tiga) kelompok kekerabatan, yaitu (a) $\mathbf{S i m}^{1}$ (keluarga batih/inti), (b) Rum ${ }^{2}$ (keluarga luas), dan (c) Keret $^{3}$ (klen kecil). Menurut Sam Kapisa (informan), sejak dulu satu keluarga luas biasanya menempati sebuah rumah tradisional berukuran besar yang biasanya disebut Aberdado.

\footnotetext{
3 Keret; kelompok kekerabatan yang terdiri dari gabungan keluarga luas yang merasakan diri berasal dari seorang nenek moyang (klen kecil).
} 


\section{Religi}

Sejak dahulu orang Biak telah mengenal sistem kepercayaan kepada Dewa Tertinggi, yang dalam bahasa Biak disebut Manggundi (Dia Sendiri). Orang Biak yakin bahwa Manggundi bersemayam di langit, sehingga mereka menyebutnya Manseren Nanggi (Tuhan atau Sang penghuni langit). Dalam perspektif orang Biak, Manggundi diyakini sebagai pencipta alam semesta beserta segala isinya. Didalam melakukan upacara untuk menghormati Manseren Nanggi, orang Biak sering melakukan Wor Fan Nanggi. ${ }^{4}$ Wor Fan Nanggi biasanya dirayakan pada waktu dan peristiwa tertentu, misalnya didalam merayakan panen, mengusir wabah penyakit, meminta hujan dan sebagainya. Pelaksanaan Wor Fan Nanggi seringkali dipimpin oleh seorang shaman, yang disebut Mon.

\section{Kesenian}

Kesenian merupakan salah satu dari 7 (tujuh) unsur kebudayaan, dimana unsur tersebut terbagi lagi kedalam beberapa sub, yaitu antara lain seni rupa (seni lukis), seni ukir dan pahat, seni bangunan (arsitektur), seni suara / seni musik, seni tari, seni sastra dan dramatik. Semuanya ini selalu menonjolkan sifat dan cirri khas kebudayaan suatu etnik / suku bangsa atau negara. Setiap kelompok etnis (suku bangsa) atau negara memiliki kesenian yang mempunyai cirri khas tersendiri.

Dalam kebudayaan orang Biak, secara tradisional kesenian tidak dapat dipisahkan pada kehidupan religius mereka, seperti halnya kesenian tradisional orang Biak, terutama seni ukir, tari dan seni musik /vokal mereka.

\section{Seni Ukir}

Salah satu ekspresi seni budaya yang paling menonjol di Papua adalah seni ukir. Orang Biak sebagai salah satu etnik yang ada di Papua, memiliki kebudayaan mengukir

\footnotetext{
4 Upacara memberi "makan" atau sesajen kepada Tuhan Langit
}

yang sudah dikenal sejak turuntemurun. Peranan dan fungsi mengukir yang ada pada orang Biak, digunakan untuk penyampaian pesan, simbol-simbol tertentu dan sebagai bagian dari seni itu sendiri.

Ada beberapa jenis ukiran yang dikenal oleh orang Biak, seperti seni ukir dengan motif dua dimensi dan tiga dimensi. Ukiran dengna motif dua dimensi, misalnya terdapat pada ukiran muka perahu, sedangkan ukiran tiga dimensi terdapat pada ukiran patung Karwar.

\section{Seni Tari}

Pada umumnya gerak tari tradisional suku-suku yang ada di Papua hampir sama, yaitu gerakan tarinya bertumpu pada kaki dan pinggul, sedangkan tangan dan bagian-bagian lainnya hanya untuk mengimbangi badan. Telah di kemukakan di atas bahwa pada umumnya bagi orang Papua, upacara, tari dan yanyian merupakan suatu kesatuan yang tidak dapat dipisahkan. Orang Biak merupakan salah satu suku di Papua yang juga menganut hal yang sama, dimana ketiga unsur tersebut di atas tidak bisa dipisahkan.

Tari merupakan bagian dari Wor (Upacara Adat) dimana Orang Biak menyebutnya dengan dua istilah yang mempunyai arti yang sama, yaitu Imas dan Ifyer. Imas yaitu gerakan tari yang dilakukan oleh laki-laki, sedangkan $i$ fyer yaitu gerakan tari yang di lakukan oleh Wanita. Imas (gerakan tari laki-laki) ini ada 4 jenis gerak tari yang sering dibawakan dalam satu tarian utuh.

\section{Seni Suara dan Musik}

Telah disinggung sebelumnya bahwa wor mempunyai arti yang luas yaitu menyangkut segala aspek yang ada didalamnya, termasuk transaksi 
makanan (fanfan dan munsasu), pembayaran mas kawin, tari adat dan nyanyian adat. Namun dalam penulisan lain mengemukakan bahwa wor mempunyai dua arti, yaitu : (a) wor sebagai upacara dan (b) wor sebagai nyanyian adat. Dalam bagian ini kita akan membahas wor sebgai upacara tradisional atau adat dan sebagai nyanyian tradisional / adat.

Dalam tari tradisional orang Biak mempunyai fungsi sosial yang ada hubungan dengan sistem kepercayaan mereka. Orang Biak menyelenggarakan Wor (upacara) untuk melindungi anak dalam tahapan perkembangan hidupnya selalu didukung dengan tari dan nyanyi yang ada hubungan atau mempunyai nilai religius. Mengapa dikatakan demikian ? Karena apabila dilihat dari latar belakang menyelenggarakan Wor (upacara) dalam lingkaran hidup mereka yang didukung dengan vokal (dow) dan tari adalah semata-mata untuk melindungi anak dari bahaya. Misalnya Kankarem digelarkan dalam Wor (upacara-upacara adat) yang bertujuan untuk melindungi individu (seorang anak) dalam momen-momen peralihan dari suatu tingkat kehidupan ke tingkat kehidupan yang lain.

Karena dalam pandangan hidup orang Biak, momen peralihan itu penuh dengan bahaya yang nyata maupun yang tidak nyata (alam gaib/ dasor ). Menggelar tari dalam upacara untuk menunjukan kepada khalayak ramai (anggota masyarakat) bahwa suami dari anak perempuan atau saudara perempuan mampu menyelenggarakan Wor (upacara adat) untuk kerabat istri. Upacara ini menunjukan bahwa pihak suami dari anak atau saudara perempuan mampu hingga menyelenggarakan Wor. Wor juga merupakan suatu indikator yang mengukur kemampuyan suatu keret yang juga sekaligus mengikat hubungan kerabat suami dan kerabat istri.

\section{METODE PENELITIAN Paradigma penelitian}

Dalam penelitian tradisi Snap Mor di Biak menggunakan paradigma penelitian kualitatif, dengan menggunakan metode analisis secara deskriptif. Penelitian kualitatif menurut Cresswel (2010), merupakan metode-metode untuk mengeksplorasi dan memahami makna yang oleh sejumlah individu atau sekelompok orang diangap masalah sosial atau kemanusian. Lebih lanjut Cresswel mengatakan proses penelitian kualitatif melibatkan upaya-upaya penting seperti mengajukan pertanyaan-pertanyaan dan prosedur-prosedur, mengumpulkan data yang spesifik dari partisipan, menganalisa data secara induktif mulai dari tema-tema khusus ke tema-tema yang umum, dan menaksir makna data.

\section{Teknik Pengumpulan Data}

Dalam penelitian dan perekaman tradisi Snap Mor di Biak, teknik pengumpulan data yang dipergunakan, untuk dapat menjaring data dilapangan sesuai dengan masalah penelitian yang ingin dikaji digunakan beberapa teknik pengumpulan data yaitu: 1) Studi Pustaka Teknik ini digunakan untuk memperoleh data sekunder, atau data pendukung., 2) Observasi. Teknik observasi dilakukan untuk menjaring data berdasarkan pengamatan yang dilakukan selama dilapangan. 3) Wawancara. Teknik wawancara digunakan untuk melakukan wawancara perinforman. Selain teknik pengumpulan data yang dikemukakan di atas, teknik lain yang digunakan adalah: melakukan perekaman.

\section{Informan}

Untuk memperoleh para informan yang dirasa mengetahui dan memahami dengan baik tradisi Snap Mor di Biak tim 
menggunakan digunakan teknik purposive sampling, berdasarkan kriteria yang telah disusun yaitu; usia diatas 25 tahun, terdiri atas tokoh adat, tokoh masyarakat, tokoh agama, tokoh perempuan dan tokoh pemuda, jumlah informan sekitar 20 Orang.

\section{Lokasi}

Kegiatan penelitian dilakukan di kampung Swapodibo, Yenures, Samber, Karninidi dan Sansudi alasan pemilihan kampung-kampung ini karena mereka memiliki model Snap Mor yang berbedabeda terutama peralatan yang digunakan untuk menangkap/menjaring ikan. Selain kampung-kampung tersebut mewakili kampung lainnya sebagai lokasi pengambilan sampel dan potensial untuk dapat dijadikan sebagai lokasi pelaksanaan snap mor oleh penduduk setempat. Sedangkan untuk perekamantari penyambutan, mengambil lokasi di Kampung Yenures, Biak.

\section{Analisis Data}

Analisa data merupakan proses berkelanjutan yang membutuhkan refleksi terus-menerus terhadap data, mengajukan pertanyaan-pertanyaan analitis, dan menulis catatan singkat sepanjang penelitian (Creswell, 2010:274). Model analisis data yang dipakai dalam penelitian danperekaman tari penyambutan, adalah model analisis data dalam penelitian kualitatif menurut Creswell (2010:277).

\section{E. HASIL PENELITIAN DAN PEMBAHASAN}

\section{Pengertian "Snap Mor"}

Sistem Pengetahuan adalah segala sesuatu yang diketahui manusia tentang benda, sifat, keadaan, dan harapan-harapan, sehingga dapat dikatakan bahwa Sistem Pengetahuan dimiliki oleh semua suku bangsa di dunia. Mereka memperoleh pengetahuan melalui pengalaman, intuisi, wahyu, dan berpikir menurut logika, atau percobaan-percobaan yang bersifat empiris.

Secara harfiah dalam bahasa Biak kata "Snap Mor" terdiri dari dua suku kata yang berbeda namun mengandung makna sama. "Snap" adalah "Koral atau Batu ( Bhs Indonesia ) yaitu sejenis hamparan bebatuan yaitu jenis batu kecil yang biasanya terhampar di muara sungai,kali,dan canal. Juga koral bentuk kecil terhampar dekat batas pantai. Sedangkan kata"Mor" adalah tumpukan koral yang sengaja dikumpul berbentuk hitungan kubuk M2,( Batu berbijibiji=bulat-bulat )dikumpul jadi satu. Jenis koral atau bebatuan ini bervariasi dari yang kecilsedang,dan besar. Selain itu terdapat juga pengertian lain dari kata Snap Mor yaitu "Mor" artinya besar atau yang utama "Nyan ( Bhs Biak ) atau Jalan ( Bhs Indo ) artinya Utama atau jalan besar-butiranbulat menumpuk besar jadi satu. Namun dalam perkembangannya. "Snap Moor “ adalah cikal bakal dari apa yang dikenal dengan" Aker" yaitu salah satu pola dan tradisi penangkapan ikan masyarakat Biak dengan mengurai tumpukan koral membentuk pagar sekaligus sangkar.

\section{Proses "Snap Mor"}

Snap Mor bagi orang Biak biasanya dilakukan dengan suatu persiapan terlebih dahulu yaitu: menyangkut lokasi, waktu pelaksanaan snap mor, jalur air pasang surut, memilih lokasi yang terlingkung dari gelombang saat air surut. Selain itu mempersiapkan pula batu karang, jaring, perahu, menentukan banyaknya orang yang ikut dalam kegiatan snap mor,

\section{Makna dan Fungsi Snap Mor Dalam Budaya Orang Biak}

Secara umum makna dan fungsi dari Snap Mor tersebut sejak dahulu sampai sekarang tiidak banyak mengalami perubahan, seperti :

a) Fungsi Sosial, Snap Mor dikatakan memiliki nilai sosial sebab mulai dari awal perencanaan sampai membagikan hasil tangkapan dalam kegiatan Snap Mor melibatkan semua orang tanpa mengenal batasan, baik mulai dari para orang Tua sampai anak-anak. Pada saat kegiatan Snap Mor sering terjadi proses sosial terutama 
muda mudi dan teman juga kerabat yang selama ini masing-masing sibuk dengan kegiatannya pada saat Snap Mor tersebut dapat bertemu di lokasi kegiatan.

\section{b) Fungsi Kerjasama}

Fungsi kerjasama yang dapat dilihat dalam kegiatan Snap Mor terutama adalah antara perempuan dan lakilaki, antara yang muda dan yang tua. Seperti kita ketahui bahwa bagi orang Biak MOR memiliki prinsip untuk orang banyak.

\section{Pelestarian Tradisi Snap Mor Oleh Masyarakat Biak dan Pemerintah Daerah}

Sebagai salah satu budaya kemaritiman orang Biak maka tradisi Snap Mor atau cara penangkapan ikan oleh masyarakat Biak sejak dahulu sampai sekarang masih di pertahankan oleh mereka. Hal ini dapat dilihat dari setiap kampung hanmpir setiap tahun melakukan Snap Mor, dan beradasarkan hasil wawancara di lapangan menunjukan bahwa budaya ini masih terus diajarkan kepada anak-anak mereka sebagai penerus dari kebudayaan Biak.

Walaupun saat ini telah banyak perubahan dalam aspek peralatan dan cara penagkapan ikan namun bagi orang Biak Snap Mor tetap harus dilakukan, sebagai bagian dari menjaga tradisi nenek moyang mereka tetapi juga nilai-nilai yang terkandung di dalam kebiata tersebut. Jadi bagi orang Biak Snap Mor bukan hanya tentang menangkap ikan tetapi filosofi dibalik kegiatan tersebut yang menjadi penting yaitu ; kebersamaan, adil dan menjaga hubungan sosial dengan orang lain.

Sedangkan dari aspek pemerintah daerah perhatian terhadap budaya suku Biak cukup baik hal ini dapat di lihat dari program yang dilakukan oleh pemrintah daerah khsusunya instansi terkait yaitu Dinas Kebudayaan. Salah satu progam perlindungan terhadap nilainilai budaya lokal yaitu dengan mengadalan Festifal Biak Munara Wampasi atau yang dikenal dengan nama "BMW". Dalam even BMW tahun ini salah satu atraksi budaya yang ditampilkan adalah "Snap Mor" selain pemukulan seribu tifa dan kapal Wairon. Menurut kepala Dinas Kebudayaan bahwa tahun depan mereka akan terus melakukan kegiatan-kegiatan serupa sebagai bagian dari pelestarian kebudayaan suku Biak di Kabupaten Biak Numfor. Bagi kepala Dinas dan pemerintah daerah Kabupaten Biak hal ini menjadi penting karena melihat perkembangan saat ini yang begitu pesat membuat beberapa budaya orang Biak telah tergeser atau bahkan hilang, oleh karena itu sudah menjadi tugas pemerintah daerah untuk melestarikannya sesuai dengan amanat undang-undang dan harapan mereka kiranya ada perhatian lebih dari pemerintah Provinsi maupun Pemerintah Pusat dalam kegiatan-kegiatan serupa di waktu yang akan datang di kabupaten Biak Numfor.

\section{F. KESIMPULAN}

Sesuai dengan hasil temuan lapangan yang telah di bahas pada bab 3 sebelumnya, maka dalam penelitian dan perekaman tentang "Snap Mor" Tradisi Penangkapan Ikan Orang Biak dapat kami simpulkan beberapa hal berikut ini ;

1. "Snap Mor" adalah salah satu sistem pengetahuan masyarakat Biak dalam cara penangkapan ikan dan setiap kampung memiliki cara atau model Snap Mornya masing-masing sesuai kondisi geografis kampungnya.

2. Kata "Snap Moor" dalam bahasa Biak terdiri dari dua suku kata yang berbeda namun mengandung makna sama. "Snap" adalah "Koral atau Batu yaitu sejenis hamparan bebatuan yang biasanya terhampar dimuara sungai,kali,dan canal. Juga koral bentuk kecil terhampar dekat batas pantai. Sedangkan kata"Mor" adalah tumpukan koral sengaja dikumpul dikumpul jadi satu. 
3. Dalam proses melakukan Snap Mor di butuhkan peralatan seperti ; batu karang, jaring, perahu, kalawai, ret atau sumpit dan parang serta kantong / noken. Snap Mor biasanya dapat dilakukan di musim Wampasi yaitu bulan Maret sampai Agustus dan Wambarek bulan September sampai Februar. Snap Mor juga dapat dilakukan pada pagi hari maupun malam hari.

4. Snap Mor masih tetap dilakukan oleh Orang Biak sampai saat ini sebab selain merupakan warisan nenek moyang juga karena nilai-nilai yang terkandung di dalamnya sperti nilai kebersamaan, kerjasama, keadailan atau penyemerataan dan nilai sosial lainnya.

5. Pemerintah Daerah Kabupaten Biak Numfor juga telah mengambil peran penting dalam pelestarian budaya lokal orang Biak dengan beberapa program unggulan salah satunya adalah Biak Munara Wampasi atau BMW. Dan di tahun 2017 ini salah satu even yang ditampilkan dalam BMW adalah Tradisi Snap Mor.

\section{DAFTAR PUSTAKA}

Ahimsa-Putra, H.S. 2002. Tanda, Simbol, Budaya dan Ilmu Budaya. Yogyakarta. Fakultas Ilmu Budaya Universitas Gadjah Mada.

BAPPEDA Rokan Hilir. 2005. Profil kabupaten Rokan Hilir. Bagan Siapiapi.

Dinas Budpar dan P2BKM-UNRI. 2003.Budaya Tradisional Bengkalis. Pekanbaru.

Tradisional Melayu
Pekanbaru..

Dinas Pariwisata, Seni Budaya, Pemuda dan Olahraga dan Pusat Studi Pariwisata. Universitas Gadjah Mada. 2006. Master Plan Pariwisata
Kabupaten Rokan Hilir. Bagan Siapiapi.

Evawarni dan Sindu Galba. 2005. Kearifan Lokal masyarakat Adat Orang laut Di Kepulauan Riau. Tanjungpinang. Depbudpar, BKSNT.

Harsono, T.Dibyo. 2001. Kearifan Tradisional Pada Masyarakat Melayu. (Proposal). Tanjungpinang. BKSNT.

Harto, Zulkifli dan Novendra. 2006. Kearifan Lokal Masyarakat Adat Propinsi Jambi. Tanjungpinang. Depdubpar, BKSNT.

Koentjaraningrat. 1978. Masyarakat dan Kebudayaan di Indonesia. Jakarta. Gramedia.

\section{Penelitian Masyarakat. Jakarta. Gramedia.}

Kusmayadi dan Endar Sugiatro. 2000. Metodologi Penelitian Dalam Bidang Kepariwisataan. Jakarta. PT. Gramedia Pustaka Utama.

Marpaung, Happy. 2002. Pengetahuan Kepariwisataan. Bandung. Penerbit Alfabeta.

Mikkelsen, Britha. 2003. Metode Penelitian Partisipatoris dan UpayaUpaya Pemberdayaan: Sebuah Buku Pegangan bagi Para Praktisi Lapangan. Yayasan Obor Indonesia.

Nuh, Imran. Kearifan Lokal Dalam Menata Lingkungan Yang harmonis. (Proposal). Tanjungpinang. BKSNT.

Pemda Kab. Rokan Hilir. 2002. Rencana Induk Pariwisata Daerah kabupaten Rokan Hilir. Bagan Siapi-api. Dinas Pariwisata, Seni Budaya, Pemuda dan Olahraga.

Purba, Jonny. 2005. Pengelolaan Lingkungan Sosial. Jakarta. Yayasan Obor Indonesia.

Refisrul, dkk. 1992/1993. Upacara Tradisional Membuka Tanah Pertanian Di daerah Riau. Tanjungpinang. Depdikbud.

Rumansara E.H, Sistem Religi Orang Biak, Uncen Press 2015 


\section{6 | JURNAL ILMU BUDAY A}

Volume 6, Nomor 2 Desember 2018

Singarimbun, Masri dan Sofian Effendi (ed). 1987. Metode Penelitian Survey. Jakarta. LP3ES.

Sumintarsih, dkk. 2005. Kearifan Lokal Di Lingkungan Masyarakat Nelayan Madura.Yogyakarta. BKSNT

Suyami, dkk. 2005. Kearifan Lokal Di Lingkungan Masyarakat Nelayan Jepara Jawa Tengah. Yogyakarta. BKSNT.

Winoto, Gatot, dkk. 1992/1993. Kearifan Tradisional Masyarakat Pedesaan Dalam Upaya Pemeliharaan Lingkungan Hidup Di Daerah Riau. Tanjungpinang Depdikbud.

Windy Hapsari, dkk (2015), Masyarakat Nelayan di Kampung Fanjur di Kabupaten Supiori.

Yayasan Kehati. 2000. Kerusakan Lingkungan Mengancam Keanekaragaman Hayati. Jakarta.

Zacharias, danny, dkk. 1984. Metodologi Penelitian Pedesaan. Jakarta. CV. Rajawali. 